\title{
OCCURRENCE OF Diphyllobothriasis IN HUMAN FROM KURDISTAN REGION, IRAQ.
}

\author{
Karwan, S. Al-Marjan \\ Pharmacy Dept. Medical Technical Institute. Hawler Polytechnique University, Erbil/Iraq \\ E-mail: Almargankarwan@yahoo.com
}

\begin{abstract}
A man of 42 yare, from Merga -Sur village (135km to the northwest of Erbil city, Kurdistan Region, Iraq) was complaining of the presence a small white fragments in his stool. Morphological examination of these piceces, macroscopically and confirmed that the patient was affected with the broad fish tapeworm Diphyllobothrium latum which is cause diphyllobothriasis. He was treated with antihelminthes (praziquantel, $10 \mathrm{mg} / \mathrm{Kg}$ single dose) in the hospital.

Keywords: Diphyllobothrium latum, Diphyllobothriasis, Erbil.
\end{abstract}

Received: 17/22013, Accepted: 11/11/2013.

\section{INTRODUCTION}

Diphyllobothriasis is caused by intestinal infections of the adults of certain species of the pseudophyllidean tapeworm like Diphyllobothrium latum also known as broad fish tapeworm the humans become infected by ingesting the larval stages (plerocerocoids) in raw or insufficiently cooked fish like domestic salmon, cherry salmon, red-lip mullet, pike, perch, rainbow trout, lake trout, burbot ect. (Dick et al., 2001). Intestinal worm infections are still the most common public health problem in the world (Jarallah, 2012). World health organization reported about 3.5 billion people were affected with intestinal parasite infection (Anonymous, 1998). This tape worm can be single or multiple and may result in symptoms such as fatigue, weakness, parasthesia, diarrhea, abdominal pain, nausea, eosinophilia, toxemia, malnutrition craving for salt and a minority of patients develop vitamin B12 deficiency, apparently because of vitamin B12 absorption by the adult worms which is lead to pernicious anemia (Got et al., 2007). Several other species of Diphyllobothrium have been described from human but less frequently they include, D. klebanovskii, D. pacificum, $D$. cordatum, D. ursi, D. dendriticum, D. lanceolatum, D. dalliae, and D. yonagoensis (Devi et al., 2007.)

\section{MATERIALS AND METHODS}

The adult stage of the worm was received from the patient after treatment then transported to the laboratory of Medical Technical Institute. Examination of worm morphology macroscopically and microscopically were done. Eggs were derived from the gravid segments of the worm (Ethyl-acetate sedimentation technique) then placed on the clean slide with a drop of normal saline (Al-Hadithi and Habash, 1986). while the gravid segments and the scolex were fixed in 10\% alcohol formalin and acetic acid fixative then stained with Aceto-Carmin (Devi et al., 2007 ). Slides were examined microscopically (using 40X and 100X magnification for eggs examination and $4 \mathrm{X}$ for gravid segments and scolex examination). Photos were taken with Sony Syber Shot Digital camera model No. DSC-P73. Measurements of the parasite were taking by using an Olympus ocular micrometer.

\section{RESULTS AND DISCUSSION}


Parasite: Diphyllobothrium latum Linnaeus, 1758.

Host: Human (final host), 42 -yare- old man.

Site of infection: Intestine.

Locality: Merga-Sur village, $135 \mathrm{Km}$ northwest of Erbil city, Kurdistan region, Iraq.

This old male was affected with diaphyllobothriasis in Merga-Sur, the patient had a history of eating different types of fish during fishing especially carps which were very common in Kurdisatan region. The result which were record on the patient before treatment period in the hospital include slightly decreasing of haemoglobin $(11.3 \mathrm{Mg} / \mathrm{dl}$, normal rang is $15.5 \pm 2.5 \mathrm{gm} / \mathrm{dl})$, normal white blood cells $8500 \mathrm{cells} / \mathrm{cu}$ $\mathrm{mm}$ (normal rang 4000-11000 cells/cu mm) little increase of erythrocyte sedimentation rate $24 \mathrm{~mm} / \mathrm{hr}$. (normal range for male below 50 year is $15 \mathrm{~mm} / \mathrm{hr}$.) and the blood pressure within the normal rang $11.5 \mathrm{~mm} / \mathrm{Hg}$. Abdominal pain, weakness, nausea and diarrhea some time replaces by constipation were also recorded. The reported case is very similar to those reported in North America (Dick et al., 2001), Saudi Arabia (Alkhalifa et al., 2006), Malasia (Rohela et al., 2006), South India (Devi et al., 2007) and Japan (Got et al., 2007). The patient was treated with antihelminthes (praziquantel,10mg/Kg single dose) in the hospital and the whole body $8.3 \mathrm{~m}$ of the parasite was isolated from the patient (Fig. 1 A) after treatment period. The body of the parasite composed of three main parts, scolex, neck and segments (strobilla). In the present study only the eggs, scolex and gravid segments were described because all the three mentioned parts have a main characteristic features which are very important for the diagnosis of the this parasite. In the present study the eggs were not isolated from the patient stool because the patient was treated in hospital but the whole body of the worm was present in the laboratory within 24 hours after worm fall down from the patient body while the eggs were isolated from the gravid segments of the worm after segment capturing by small needle then slides were prepared by ethyl-acetate sedimentation technique. Egg is operculated at one side and abopercular protuberance at another side. Its oval in shape 58-70 $\mu \mathrm{m}$ with moderately thick-shelled Fig. (1E). There are a similarity between the eggs of $D$. latum and D. pacificum. The eggs of both of them are oval in shape and operculated but the later is moderately smaller in size 40-60 $\mu \mathrm{m}$ and have a thicker egg shell. Diphuyllobothrium eggs some time confused with the eggs of Taenia saginata and Taenia solium during the examination of patient stools but there are some distinguishable features which solve this problem the best of them is radially striated egg shell in $T$. saginata and $T$. solium compared with smooth lined egg shell in D. latum (Rohela et al., 2006 ). The scolex of this parasite act as a sucking and attachment part to human intestinal mucosa which is spoon shaped $0.8 \mathrm{~mm}$ in width and has a characteristic of pseudophyllidean grooves (bothria) instead of suckers and hooks which are present in other tapeworm like Taenia sp. Fig.(1 B). Macroscopically, the segments are broader than longer, 4-6mm in long and 7-10 $\mathrm{mm}$ in width Fig. $(1, \mathrm{C})$. This rang depend on the maturation degree of segments (mature, immature and gravid segments). Microscopic examination of the segments with Aceto Carmin shows the medial genital pores and uteri forming a rosette (Fig. $1 \mathrm{D}$ ) which is a basic characteristic feature of the D. latum (Rohela et al., 2006). Our description and measurement are similar to those reported by Devi et al., (2007) and Scandrett, (2007).

This reported case, the most probable source of infection was fish because the patient had a history of fishing and fish eating especially various carps because this 
type of fish are very common in Kurdistan region. The infective stage of this parasite is plerocerocoid larval stage occur in fish muscles (intermediate host), thus eating of raw or undercoccked fish meat cause infection. The fisher man sometimes eats undercooked fish meat at the site of fishing which may lead to this infection. Fish related parasites infections were varied from one region to another. Factors which increased the rate of infections by intestinal diphyllobothriasis from one region to another, these includes environmental factors, personal hygiene, population and personal behaviors, poor sanitary and climatic factors.

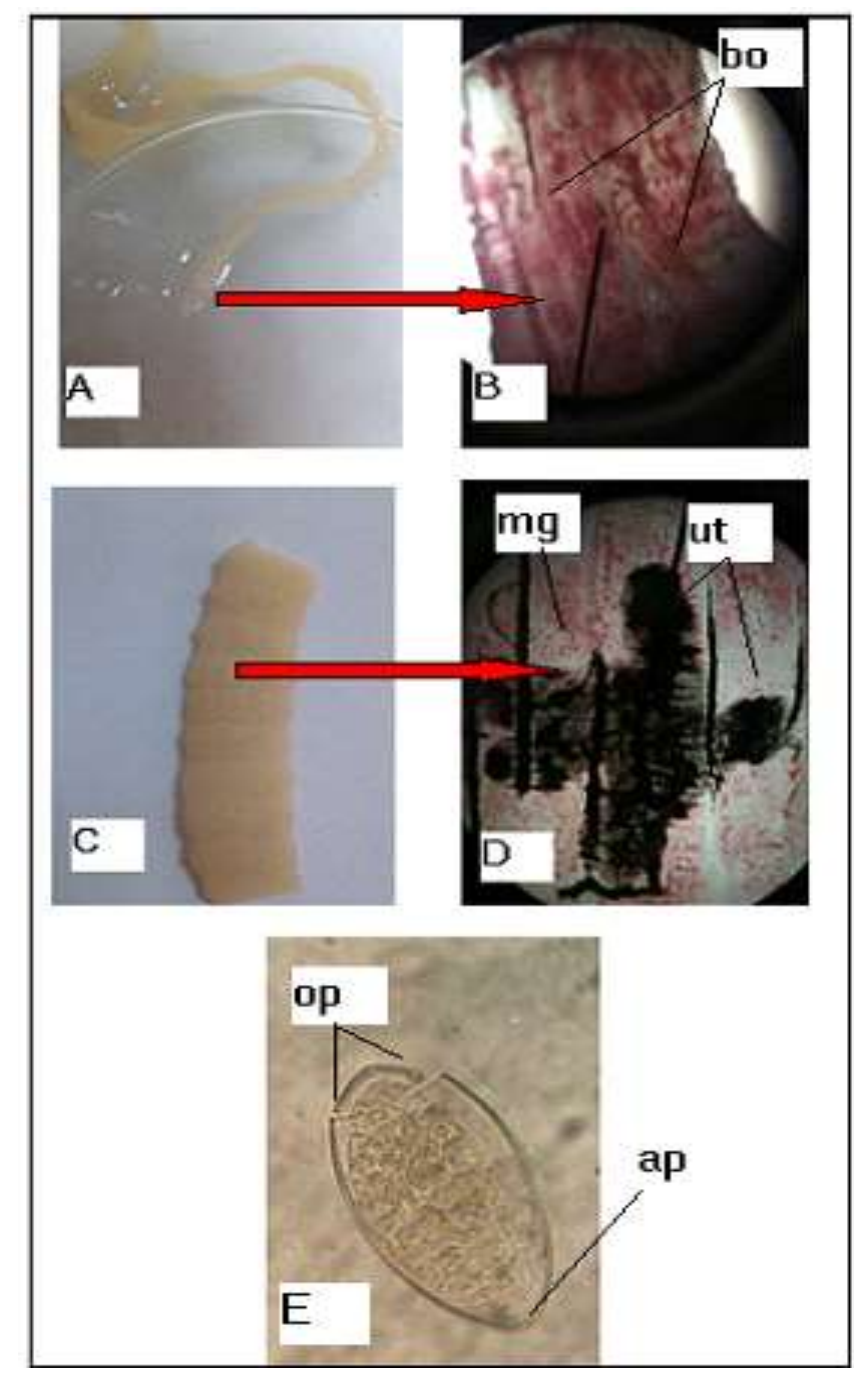

Figure (1): Photomicrograph of Diphyllobothrium latum

A- The whole body of the parasite.

B- Enlargement of the scolex stained with Aceto Carmine solution showing suctorial grooves or bothria (bo) (40X).

C- Proglottids of the adult worm showing each segment with width more than length.

D- The gravid proglotid showing rosette shape utri (ut) and medial genital pore (mg) (40X).

E- Egg, note the operculum (op) and abopercular protuberance (ap) (400X).

Merga-Sur village $135 \mathrm{~km}$ far from Erbil city (northwest of Erbil city) and this village have very cold climate during winter thus the occurrences of worm may due to 
cold climate because depending on a checklist which were collected on this parasite (Dick et al., 2001 ), the data reveals the high prevalence of infections in the cold climate countries for example 21 cases in New York, 309 cases in USA and 95 cases in Canada in addition to 43 cases which were reported in Republic of Korea (Lee et al., 2007 ). However only one case of this infection was recorded from each of the Saudi Arabia, Jordan and Iran (Alkhalifa et al., 2006; Abo-Shehada, M. N. and Ziyadeh, 1991 and Mokhayer, 1981). Environmental factors including the biological factors determine the prevalence of infections by this parasite example presence or absence of the specific intermediate host (fish) for this parasite. Wardll (1933) suggested that plerocercoids of $D$. latum were found in the musculature of only the following species of fish, pike (Esox lucius), yellow perch (Perca flavescens), walleye (Stizostedion vitreum), sauger (S. canadense) and burbot (Lota lota) However, the decades of survey work after that Dick et al., (2001) saw D. latum reported from salmonid fishes and Pike with some percids in North America and Holarctic (many of the habitats found throughout the northern continents of the world) respectively. Esox lucius, Perca flavescens, Stizostedion vitreum, S. canadense and Lota lot were not recorded in Iraq depending on checklist which was prepared by Coad in 2010 on the fresh water fish in Iraq and this leads to decrease the prevalence of infection among human in Iraq because fish act as second intermediate host and play an important role for the continuous of the life cycle of $D$. latum. In addition to cyprinid fish another probable source of infection was eating salmonid fishes because salmon lively were introduced from Iran to Kurdistan markets via Hagi Omran passage way near Merga-Sur village. In 1987 only the larval stage, plerocercoids of this parasite was identified from a cyprinid fish, Acanthobrama centisquama and unknown species in Brbus grupus, from Tigris river, Baghdad (Ali et al., 1987 ) while in 2010, low prevalence of infection (\%2) by the adult stage of D. latum was recorded in stray dogs of Kalar city, Sulaimani province (Bajalan, 2010). In the present investigation only the adult stage of Diphyllobothrium latum was recorded for the first time in the hospitals of Kurdistan region, Iraq depending on the hospital recorders without the recording of new intermediate host (fishes) for this parasite.

$$
\begin{aligned}
& \text { ظهور Diphyllobothriasis في الانسان من اقليم كردستان ، العراق } \\
& \text { كاروان سلو نجم المرجان } \\
& \text { قسم الصيدلة/المعهد الطبى التقنى/ جامعة بولتيكنيك هولير .اربيل } \\
& \text { E-mail: Almargankarwan@yahoo.com }
\end{aligned}
$$

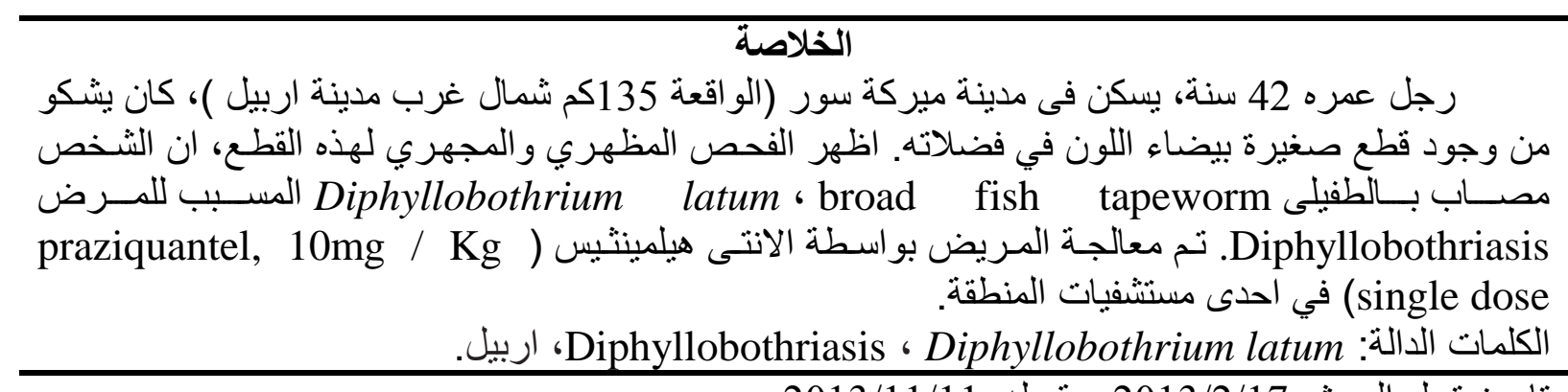




\section{REFERENCES}

Abo-Shehada, M. N. and Y. Ziyadeh, (1991). Prevalence of endoparasites in dog faecal deposits in Jordan. Journal of Helminthology.65:313.

Al-Hadithi, I. A. and A. H. Habash (1986). Parasitology. Basrah Univ.,485.

Ali, N. M.; N. E. Salih and K. N. Abdul-Ameer (1987). Parasitic fauna of some freshwater fishes from Tigris river, Baghdad, Iraq. III. Cestoda. Journal of Biology Science. 18:25-33.

Alkhalifa, I. S.; R. R. Hassan; A. Abdul-Hameed and L. Alkhayal (2006). Diphyllobothriasis in Saudi Arabia.Saudi. Journal of Medicine. 27 (12): 19011904.

Anonymous. (1998). Control of tropical diseases. World Health Organization Geneva.

Bajalan, M. M. (2010). Prevalence of intestinal helminths in stray dogs of Kalar city / Sulaimani province. Iraqi. Journal of Medical Veterinary. 34 (1): 151-157.

Coad, B. W. (2010). Freshwater Fishes of Iraq. Pensoft Publishers, Sofia-Moscow. 294.

Devi, C. Sh.; Shashikala ; S. Srinivasan ; UC. Murmu ; P. Barman, and R. Kanungo (2007). A rare case of diphyllobothriasis from Pondicherry, south India. Indian. Journal of Medical Microbiology. 25 (2): 152-4.

Dick, T. A.; A. Nelson1 and Choudhury (2001). Diphyllobothriasis: Update on human case, foci, patterns and sources of human infections and future considerations. Southeast Asian. Journal of Tropic Medical Public Health. 32 (2): 59-76.

Goto, K.; M. Hayashi; M. Inamori; T. Akiyama; T. Ikeda; K. Fujita; I. Ikeda; T. Fujisawa; H. Takahashi; M. Yoneda; K. Hara; H. Yasuzaki; Y. Abe; H. Kirikoshi and K. Kubota (2007). Gastrointestinal: Diphyllobothriasis. Journal of Gastroenterology and Hepatology. 22 : 445.

Jarallah, H. M. (2012). Intestinal parasitic infections among rural villages in Basrah marshes regions. Journal of Basrah Research Science. 38 (2) A :40-43.

Lee, E. B.; H. S. Jung; S. P. Nam; K. K. Byung; S. L. Hyung; J. H. Yoon; K. HyoJin; S. un-Hee and Ch. Jong-Yil (2007). Case of Diphyllobothrium latum infection with a brief review of diphyllobothriasis in the Republic of Korea. Korean. Journal of Parasitology. 45(3): 219-223.

Mokhayer, B. (1981). Parasites of fish in the sefid rud basin. Journal of Veterinary. 36: 61-75.

Rohela, M.; I. Jamaiah ; K. L. Goh and V. Nissapatorn (2006). A second case pf Diphyllobothriasis in Malaysia. Southeast Asian. Journal of Tropic Medical Public Health. 37 (5):896-898.

Scandrett, W. B. (2007). Improved Postmortem Diagnosis of Taenia saginata Cysticercosis. M. Sc. Thesis, Coll. of Graduate Studies and Res. Univ. of Saskatchewan Saskatoon.

Wardle, R.A. (1933). Significant factors in the plerocercoid environment of Diphyllobothrium latum . Journal of Helminthology. 1:25-44. 
Mesopotamia J. of Agric.

Vol. (45) No. (4) 2017
ISSN: 2224 - 9796 (Online)

ISSN: 1815 - 316 X (Print)

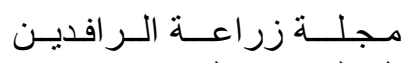

المجلد (45) العدد (4) 2017 